\title{
STAFFING FOR SCENARIOS OF SUSTAINABLE DEVELOPMENT OF KHARKIV REGION ECONOMIC SECTORS
}

\author{
UDC 331.5:502.131.1(477 Harkov) \\ Volodymyr Rodchenko, Ganna Rekun, Eugenia Naidina, \\ Yuliia Prus, Valeriia Medenets \\ V.N. Karazin Kharkiv National University, \\ Education and Research Institute "Karazin Business School”, Kharkiv, Ukraine

\begin{abstract}
The article is devoted to the study of the emergence and deepening of staffing gaps that affect the development of the region under the influence of transforming production dominants in the conditions of Economy 4.0. In the course of the study, the system of factors for the emergence of staffing gaps that affect the sustainable development of the region is generalized. A matrix approach to determining staffing gaps is proposed and sectorial scenarios for preventing them in Kharkiv region economy are developed. The assumption about the perspective structure of economy sectors in Kharkiv region according to the scenarios of inertial and innovative ways of development of Ukraine is formed.
\end{abstract}

Key words: Economy 4.0; human resources; staffing gaps; technology; sustainable development.

JEL Classification: J21, M54, R11

\section{INTRODUCTION}

Over the last decade in the conditions of Economy 4.0, the transformation of production dominants based on ICT and global automation has led to significant adjustments to existing levels of economic sectors and employment patterns (Brynjolfsson et al., 2014). Modern challenges create contradictions such as technological pressure on jobs and it determines deepening of staffing gaps in both individual regions and the country as a whole. Regular monitoring of staffing gaps allows for timely redistribution of labor force, improvement of

Received May 01, 2020 / Revised June 03, 2020 / Accepted June 08, 2020

Corresponding author: Yuliia Prus

V.N. Karazin Kharkiv National University, Education and Research Institute "Karazin Business School", Myronosytska Str., Kharkiv, 61002, Ukraine

E-mail: yuliaprus@karazin.ua

C 2020 by University of Niš, Serbia | Creative Commons Licence: CC BY-NC-ND 
education system and training of skilled and flexible workforce. Exactly these qualities of human capital are important components of competitiveness and they contribute to attracting investment and developing economics.

An increase in the employment of high-skilled workers and a corresponding decrease in employment among low-skilled workers has caused global digitalization (Balsmeier et al., 2019). Thus, in developed economies, there is a growing polarization of labor market opportunities between high-skilled jobs, unemployment and underemployment, especially among young people, and stagnant incomes for a large proportion of households (McKinsey Global Institute, 2017).

According to The Future of Jobs Report 2018 World Economic Forum, by 2022 the number of new jobs should increase from $16 \%$ to $27 \%$ of the total number of employees in large firms worldwide. However, jobs that are currently affected by lack of technology should decrease from $31 \%$ to $21 \%$ (The Future of Jobs, 2018). 75 million current jobs may be shifted because of changes in the division of labor between humans, machines, and algorithms, while 133 million new jobs may be created simultaneously (Kvasniy et al., 2014).

The transformation of production dominants in Economy 4.0 directly affects reduction and even complete destruction of jobs. According to research by Oxford University, by 2033 in the US, robots with artificial intelligence will replace $47 \%$ of workers (Vartanova, 2018, p.38).

Thus, the changes taking place in the world labor market under the influence of the transformation of production dominants in the conditions of Economy 4.0 require appropriate changes in the structure of employment and proper solutions to the issues of filling staffing gaps.

Inertial development of economic sectors of the regions of Ukraine creates an asymmetry of the regional labor market, which will become a threat to the economy as a whole in the face of new opportunities and challenges (Semykina et al., 2012).

Solving the problem of formation, use and development of human resources in accordance with the rapidly changing aspects of the external and internal environment of the country, regional or individual industry necessitates certain prospects and options for future socio-economic development of the territory.

As for the objectives of the study, the work is organized as follows: the first part of the article considers the methodology of building a matrix to study staffing gaps within the region. To determine and further forecast future strategic gaps, the analysis of the economic portfolio for each sector of the economy of Kharkiv region was used. The second part identifies the factors of strategic staffing gaps, calculates labor productivity by sectors of the economy of Kharkiv region, and applies the matrix approach to determine the mismatch of staffing needs to human resources by sectors of the economy. Also based on the scenario method, scenarios for managing strategic staffing gaps for each sector of the economy have been developed on the example of Kharkiv region. The final part of the article presents relevant conclusions of the study.

\section{Methodology}

In the course of research, the following general scientific and special methods were applied: theoretical generalization - when determining the content of the basic categories of research; content analysis and bibliographic search - when studying global trends that shape the modern workplace; logical and structural approach - when generalizing the system of 
factors for the emergence of staffing gaps for the development of the region; calculation when determining labor productivity by types of economic activity in Kharkiv region; matrix approach - when doing the strategic analysis of staffing development of Kharkiv region; scenario forecasting - when developing sectorial scenarios for Kharkiv region. The basis of sectorial scenarios of staffing is the assumption that the present and past state of the region economy determine its future to a significant extent (Kyfyak, 2016).

To determine staffing gaps using matrix approach, we propose the following methodology. According to the method of portfolio analysis, one has to determine the matrix parameters which will evaluate the efficiency of using human resources in the implementation of labor activities in foreign trade (growth rate of labor productivity by sector and relative productivity levels); to take the average values of selected parameters as such that divide the axis of the matrix in half; to calculate the values of selected parameters for each segment in the economic activity of the region; to distribute the types of economic activity of the region in one of the four quandrants of the matrix, basing on preliminary calculations; to classify the sectors of the regional economic activity by the number of the quandrant to which they belong, namely: I, II, III, IV.

The characteristics of matrix quadrants for the study of staffing gaps that affect the development of the region are given in Table 1.

Table 1 Characteristic of matrix quadrant

\begin{tabular}{lcccc}
\hline \multirow{2}{*}{ Indexes } & \multicolumn{4}{c}{ Quadrants of Matrix } \\
\cline { 2 - 4 } & I & II & III & IV \\
\hline Labor productivity & Low & High & Average & Low \\
Growth rates of labor productivity & Average / High & High & Low & Low \\
Realtive level of productivity & Low & High & Average & Low \\
Part of employees & Growing & Growing & Constant & Falling \\
\hline \multicolumn{3}{c}{ Source: Authors' }
\end{tabular}

\section{RESULTS AND DISCUSSIONS}

\subsection{Identification and analysis of staffing gaps that affect the development of Kharkiv region}

The prerequisite for the emergence of staffing gaps is the transformation of production dominants in the conditions of economy 4.0, which focuses on the mobilization of all national resources, including personnel, in order to accelerate technological changes.

Different literary sources often suggest that the broad economic impact of innovation determines such phenomena as polarization and inequality between highly qualified personnel resources in advanced industries and less qualified personnel in the field of personal services. For example, a study of cities with strong high-tech economies suggested that, though an increase in the employment of skilled workers may create new jobs for unskilled workers, the latter are still not well-paid (Lee et al., 2019).

There is another viewpoint on the relationship between innovation and employment. According to the "Theory of compensation", which was supported by such classical economists as D. Ricardo, K. Marx and others, the introduction of innovations affects the increase in labor efficiency, which in turn reflects in the growth of demand and hence 
employment (Vincent, 2018). These mechanisms have a positive effect only in competitive markets. As in monopolistic markets, where there is low elasticity of demand and no competition, the introduction of innovations in the short term can cause a reduction in employment. However, compensation mechanisms may be more or less effective in maintaining or creating new jobs, depending on existing economic conditions. The expectations of consumers and sellers also determine the extent to which the latest technologies affect employment (Nerdrum et al., 2001).

Recent studies show that patented innovations are fully friendly to employment in the newest sectors of the economy with high elasticity of demand and significant technological opportunities, in which the effect of creating new products prevails over the replacement of existing ones (medical and optical equipment, electrical appliances and electronics, etc.) (Vincent, 2018).

Meanwhile in Ukraine, more traditional and low-tech approaches to production and service prevail and this will become a threat to the staffing of the country as a whole in the conditions of new opportunities and challenges of the economy.

Factors that affect the emergence of staffing gaps (see Fig.1).

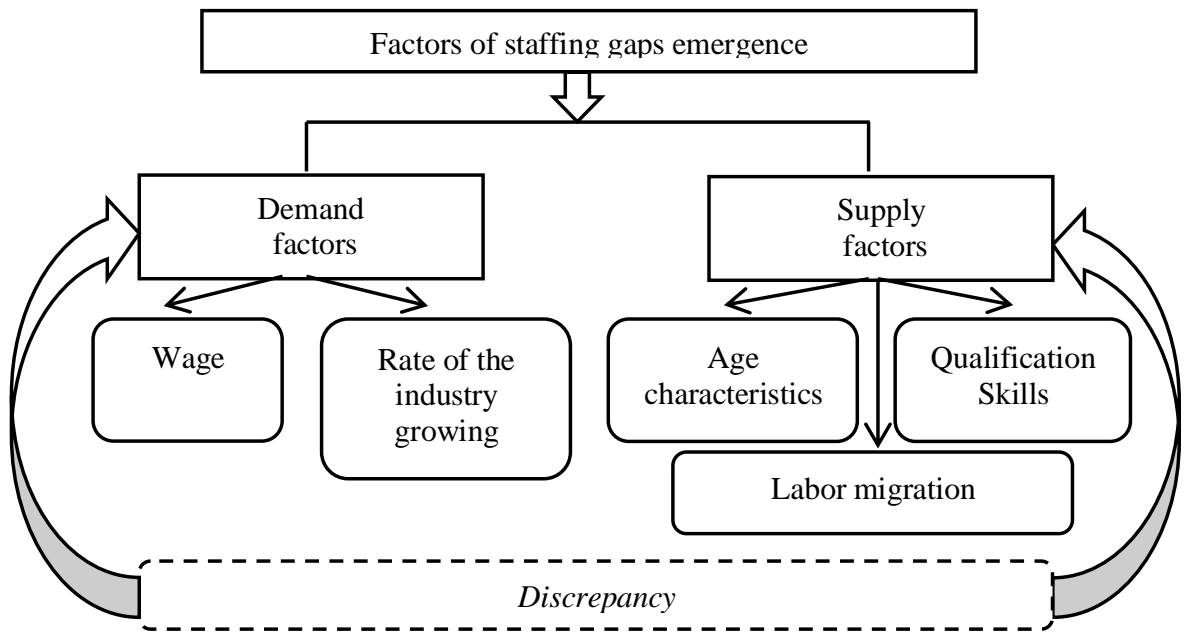

Fig. 1 Factors that contribute to the emergence of staffing gaps in the region Source: Authors'

These factors are divided into demand factors and supply factors. It is the demand factor, through the growth of supply and wages for higher salary and the desire to work in the economy with high added value, which generates a supply of workers with appropriate qualifications, an increase in working-age population and reduction in migration. Thus, staffing gaps should be considered as a mismatch between the factors of supply and demand in the labor market, namely, the mismatch of the need for personnel to the human resources potential, which has already been formed or should be formed at each level of economic activity.

Thus, the identification and analysis of "strategic staffing gaps" should be carried out on the way to the strategic management of staffing for Kharkiv region. 


\subsection{Matrix approach to the analysis of staffing gaps that affect the development of Kharkiv region}

The main criterion for the efficiency of economy, which forms the economic basis for the growth of life quality of the population, is labor productivity. The level of labor productivity against the background of market relations determines the competitiveness of the country's economy as a whole. After all, this indicator makes it possible to assess the efficiency of production of goods and services, knowledge and understanding of what is necessary for a qualitative increase in added value.

In the regional context, labor productivity is determined through the proportions of gross regional income and demand for human resources and employment of the population of the region by sectors of the economy. At the same time, the dynamics of these indicators allows us to assess the degree of increase in efficiency in the management of economic processes. The higher labor productivity in the sectors of the region economy gets, the higher the level of meeting social needs becomes and the more opportunities to reproduce the quality of human resources appear (Fagerberg, 2000).

To analyze the productivity of Kharkiv region, the following formula was used:

$$
L P=\frac{G V A n}{E n}
$$

where: LP - labor productivity by type of economic activity; GVA - gross value added; $\mathrm{E}$ - number of employees; $\mathrm{n}$ - type of economic activity.

The results of the calculations are presented in Fig. 2.

A matrix approach can be used to diagnose and further manage strategic staffing gaps in the region. It will allow us to compare the current state and dynamic characteristics of labor productivity in the region. The analysis is carried out on the example of Kharkiv region.
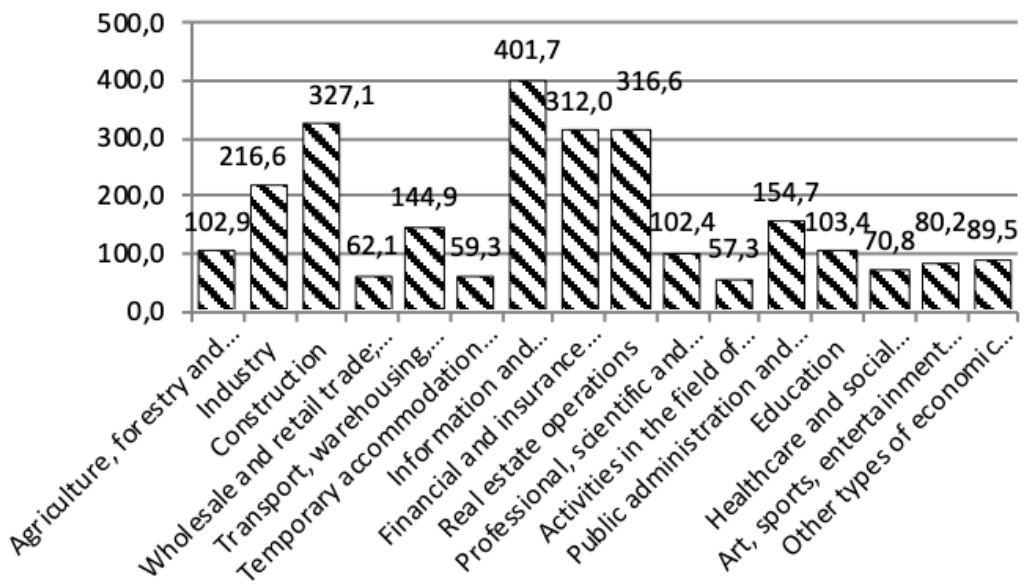

Fig. 2 Labor productivity by spheres of economic activity in Kharkiv region in 2017, thousand UAH

Source: Authors' 
The logic of the approach to the assessment of staffing gaps takes into account three features. The first one is dynamic, which is a measurement of global technological changes that determine the change in productivity of a particular industry compared to the previous periods of time. The second one is relative, which reveals the specifics of local conditions of the economy when comparing the productivity of the industry and the region as a whole. The third one is structural, which characterizes employment of a particular industry in comparison with others.

To construct the matrix we propose using the following indicators:

- growth rates of labor productivity by sectors of the economy (\%) (horizontally). Calculated as the ratio of labor productivity of a particular sector of the economy for the reporting period (2017) to labor productivity of a particular sector of the economy for the base period (2012);

- relative level of labor productivity or relative share of the economic link in terms of labor productivity (\%) (vertical). Calculated as the ratio of labor productivity of a particular sector of the economy to labor productivity in all sectors of the region;

- ball diameter is the share of employees, which is calculated as the ratio of the number of employees in a particular sector of the economy to the number of employees in the whole region in 2017.

This view allows us to identify the sectors of the economy where staffing gaps are at the high level, or which sectors are promising, or to which sectors to redistribute human resources. The appearance of gaps is associated with the imbalance of supply and demand in the labor market both in terms of the ratio of their volumes, and in the direction of professional and qualification imbalance of supply and demand. The possibilities of structural transformation of the economy largely depend on the qualitative and quantitative characteristics of the available labor force.

Thus, Quadrant I of the matrix will include sectors of the economy in which relative labor productivity is low and the growth rate of labor productivity is high. Such sectors require significant investment in their development. As a rule, these sectors are characterized by high employment, but low profitability. Those employed in such sectors tend to receive low wages, which does not attract skilled workers. For the sectors of this quadrant, interventionist measures aimed at state support of the inflow of human resources are recommended.

Quadrant II will include sectors of the economy in which the relative productivity and productivity growth are high. As a rule, these sectors of the economy are actively developing and are promising in the future. In these industries, there is high demand and supply of labor, as well as owing to retraining from other sectors.

Quadrant III will include sectors of the economy in which relative labor productivity is high and the growth rate of labor productivity is low. As a rule, these sectors of the economy have a stable demand for labor, but need constant updating of skills in order to be attractive and grow steadily.

Quadrant IV will include sectors of the economy in which both relative productivity and productivity growth are low. These sectors tend to have a slow pace of development, and therefore require measures aimed at controlled disposal of human resources on condition of providing support to such sectors.

In the course of the strategic analysis of staffing that affects the development of Kharkiv region applying the suggested approach, we used the calculations of labor productivity by the spheres of economic activity in Kharkiv region (Fig. 2), as well as the 
data of the State statistics service of Ukraine. The results of the study of staffing in Kharkiv region are given in Fig. 3.

Most sectors of Kharkiv regional economy were included in Quadrant I. Among these sectors, it is possible to distinguish those branches that provide mainly non-market services. Such services per se do not ensure conditions of economic development; the state provides and supervises their provision. This group includes the following sectors of Kharkiv region economy: "Professional, scientific and technical activities", "Healthcare and social assistance", "Education", "Art, sports, entertainment and leisure".

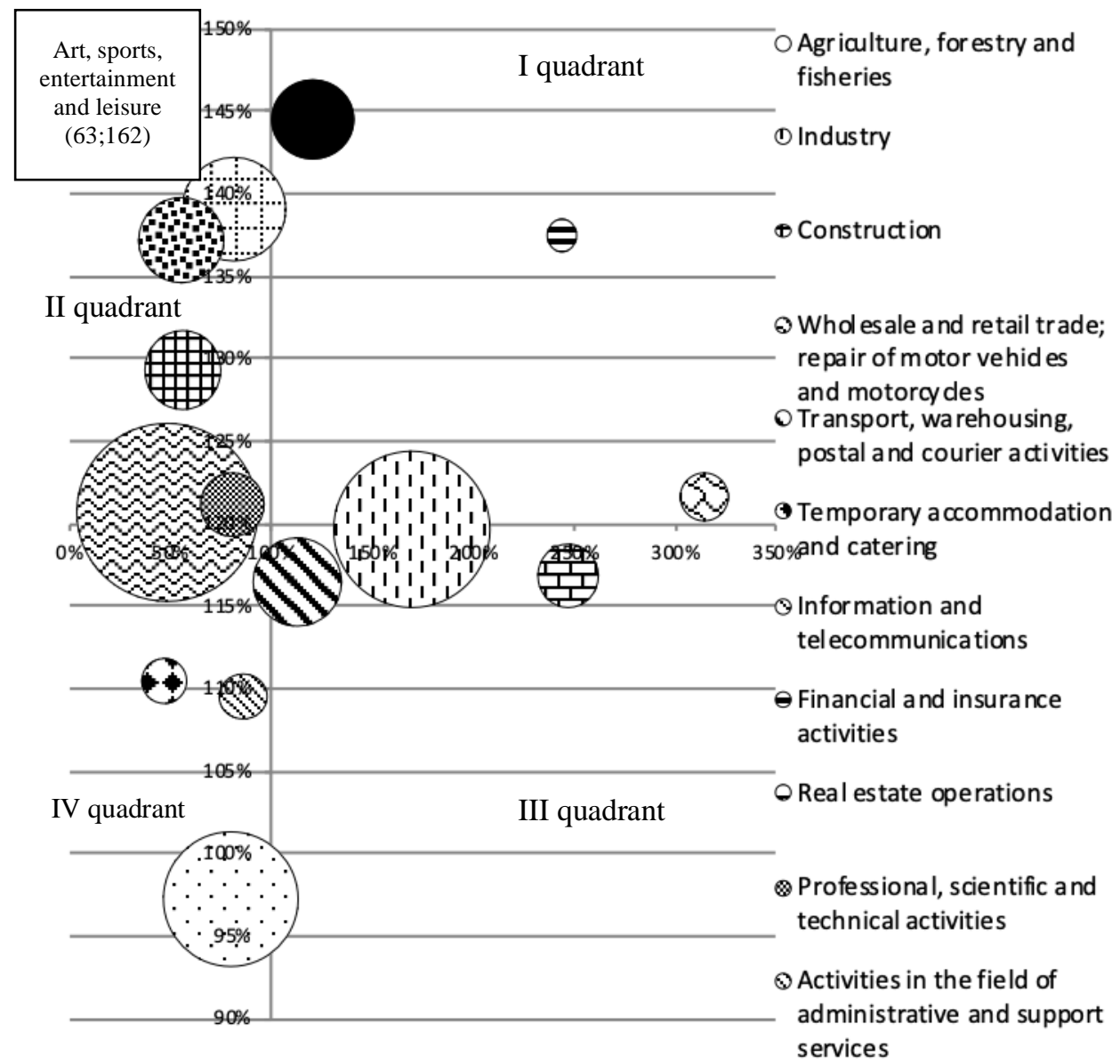

Fig. 3 Matrix of research of staffing that affects the development of Kharkiv region Source: Authors'

The low relative level of labor productivity in these industries is due to the social, auxiliary, scientific and technological basis of their functioning. The outdated system of financing and public administration limits the possibilities of creating added value in these industries. At the same time, most of these sectors of the economy have an urgent 
need for personnel because the wage is lower than the average value of the corresponding indicator in the region. It can be argued that the increase in wage in 2017 in the fields of "Professional, scientific and technical activities", "Healthcare and social assistance", "Education", "Art, sports, entertainment and leisure" by 13\%, 16\%, 21\% and 10\%, respectively had the nature of compensation. This means that the inflation rate played a key role in raising wages in these sectors of Kharkiv region economy. However, this measure did not consider the increase in prices for goods and services for the population, due to which there was a decrease in the number of employees by 1-2\% in 2017 in "Healthcare and social assistance", "Education", "Art, sports, entertainment and leisure". The functioning of these sectors of the economy is an integral element of the social infrastructure of the state. According to the authors, the growth opportunities of these sectors are determined by the possibility of transforming the model of their functioning through changing the model of public services to the model of profitable sectors of the economy with different sources of financing.

"Wholesale and retail trade; repair of motor vehicles and motorcycles" sector is also included in the quadrant. On the contrary, here we witness the largest share of employment among the industries of Kharkiv region with slightly above average growth rates of labor productivity in the region. After all, this sector of the economy is dominated by relatively low input requirements regarding the level of education of human resources, relative to other sectors of Kharkiv region economy, with an average level of real wage. Overstaffing of this economy sector determines high turnover of personnel, predominance of low-skilled personnel and a significant proportion of unofficially employed people.

Such sectors of Kharkiv region economy as "Information and telecommunications", "Industry", "Public administration and defense; compulsory social insurance", "Financial and insurance activities" fell to Quadrant II of the matrix. "Information and telecommunications" branch is characterized by high productivity among the sectors of Kharkiv region economy (as of 2017 - UAH 401.7 thousand per person). It is worth noting that the real relative share of employment in "Information and telecommunications" sector is much higher through a significant percentage of unofficial employment.

The leading consulting company PricewaterhouseCoopers conducted an in-depth analysis of the preconditions for staffing gaps by order of the IT cluster in the city of Kharkiv. It clearly shows that even IT sector that is growing rapidly and offers highly competitive wage will have staffing shortages because the lack of skilled professionals remains a significant problem today (Kharkiv IT Research, 2018).

According to Kharkiv IT-Research, in 2018, 31\% of the total number of recruited IT professionals were students (Kharkiv IT Research, 2018). Therefore, the task of managing the strategic aspects of staffing for Kharkiv region in "Information and telecommunications" sector should be to increase employment by establishing a network of contacts between universities and the private sector. Such measures will help to meet the needs of employers who search for the relevant skills of human resources.

In Kharkiv region economy, "Industry" sector also got to Quadrant II and took the second place after "Trade" sector with the proportion of the employed that remained constant in 2015 -2017. Therefore, in the context of staffing, redistribution of the employed in specified sector of Kharkiv region economy should be done among other industries that appeared in Quadrants III and IV.

As for "Public administration and defense; compulsory social insurance" sector, during 2016-2017 there was an increase in labor productivity by 44\%, its level exceeds UAH 154 
thousand per one employee. Taking into consideration the economic situation in the country, this trend of labor productivity in this industry seems illogical, despite the fact that within the framework of economic production it is considered in accordance with the SNA methodology (Kryvusha, 2017).

Quadrant III includes the following sectors of Kharkiv region economy: "Transport, warehousing, postal and courier activities" and "Real estate operations". These sectors of the economy are characterized by a high relative level of labor productivity at low growth rates of labor productivity during 2016-2017. In the context of bridging staffing gaps in the development of Kharkiv region, the main strategic impacts for economic activities that are located in Quadrant III should focus on increasing productivity growth by attracting staff to the relevant sectors through the development of locally adapted skills policies.

We should pay special attention to the sectors of Kharkiv region economy, which are located in Quadrant IV, especially "Agriculture, forestry and fisheries". After all, this sector, according to the results of the analysis, has the lowest growth rates of labor productivity (97\%) and a low relative level of labor productivity $(80 \%)$, with a significant share of employed residents of the region (13.8\%). One of the tasks of bridging staffing gaps in "Agriculture, forestry and fisheries" sector of Kharkiv region should be a set of measures to form a network of public-private partnerships to reduce the discrepancy between skills that are priority for employers and skills that human resources receive on the basis of training at the higher education institution.

\subsection{No-change scenario for different sectors of Kharkiv region economy on condition of available staffing}

One of the tools that allows us to determine the future condition and make an effective management decision taking into account the conditions, specifics and features of the territory is scenario planning. The use of this forecasting tool made it possible to form an assumption about the prospective structure of the sectors of Kharkiv region economy according to the scenarios: constant (inertial) productivity and growth of labor productivity to the world level.

According to the no-change scenario of the territorial development, relative socioeconomic stability is ensured, but there is a certain conservation of the traditional sectors of the region's economy. Due to this, the main risk of the development of economic activities on condition of available staffing is the loss of competitiveness of human resources and the region economy as a whole (Blyzniuk et al., 2018).

According to the no-change scenario, such traditional sectors of economic activity as "Industry", "Agriculture, forestry and fisheries" and "Wholesale and retail trade; repair of motor vehicles and motorcycles" will remain the basis of socio-economic development of Kharkiv region. After all, today, Kharkiv region is characterized by industrial, agricultural and trade specialization of the economy (Development Strategy of Kharkiv region, 2015).

For a certain period, specified kinds of economic activities will develop trends that have developed in 2016-2017, but in the long term, we can expect a significant reduction in GVA in the economic complex of the region, the deterioration patterns of consumption and decline in the living standards of the population as a whole.

There may be expected a slight decrease in GVA in the sectors of industry and agriculture due to the deterioration of the material and technical base and the inability to obtain funds from commercial investors. The number of the employed will remain unchanged or there will 
be a slight increase in their number at the expense of low-skilled labor. However, the increasing mismatch of skills to the needs of employers in the industrial and agricultural sectors and the spread of migration processes will deepen the acute shortage among certain specialists in these sectors of the region's economy. Thus, during 2015-2017, skilled agricultural and industrial workers were quite active before leaving abroad and accounted for $20.2 \%$ and $43.9 \%$, respectively, of the total number of labor migrants who worked before leaving abroad (Ukrainian society: a migration dimension, 2018).

As a result, the shortage of human resources of a certain profession (tractor driver, tailor, electric and gas welder, locksmith, etc.) in the mentioned sectors of economic activity can affect the aggravation of competition in the regional labor market. This trend, on the positive side, can affect the improvement of working conditions and increase the salary of a deficit worker. However, in terms of constant (inertial) labor productivity, there might appear human resources for positions that are above their skill level and available human capital (Lewis, 1954). There will also be a reduction in the production of agricultural products and an increase in the cost of production due to an increase in wage.

In "Wholesale and retail trade; repair of motor vehicles and motorcycles" sector, an increase in the number of employees is projected, a significant proportion of which will be unofficially employed persons, which reduces the possibility of increasing the degree of protection of labor and social rights of labor resources in the region. This social and economic phenomenon will affect the increase in overstaffing in "Wholesale and retail trade; repair of motor vehicles and motorcycles" sector. The following situation can lead to mass dismissal among persons who were employed in the specified sector of Kharkiv region economy during 10 years.

Under conditions of the no-change scenario for the development, Kharkiv economic branches that provide non-market services will not be able to meet social needs of the population completely due to the inability to attract funds from international grant organizations. It is expected to reduce the number of people employed in these economic activities through the preservation of compensatory nature of wages, which does not allow for the increase in prices for goods and services for the population.

There is also a threat for Kharkiv region to lose its title as "the center for educational services" because there is the lack of opportunities to update the material and technical base and infrastructure. That is why Kharkiv universities might attract students from less solvent and demanding sectors, including Asian one (Development Strategy of Kharkiv region, 2015). Thus, there might happen an outflow of the best domestic students for quality education to the capital of Ukraine or abroad. Thus, in 2016-2017 academic year, almost 77.5 thousand Ukrainian students (about $8 \%$ of the total number of full-time students) were studying abroad, which is almost three times as many as the corresponding figure in 2018 (Ukrainian students abroad, 2018).

In the sector of "Information and telecommunications" of Kharkiv region, there will be an increase in the percentage of unofficial employment with constant labor productivity. After all, according to the "Theory of compensation", the introduction of innovations to the latest sectors of economy with high elasticity of demand and significant technological capabilities affects the increase in labor efficiency, which in turn is reflected in the growth of demand, and hence employment (Vincent, 2018). At the same time, it might increase the outflow of the most qualified specialists of the IT sector abroad. In addition, the transfer of achievements of Kharkiv IT specialists abroad will increase. 
The functioning of the sectors of Kharkiv region economy under the scenario of constant (inertial) labor productivity by type of economic activity allows us to make assumptions about the future structure of the sectors of the region economy (Fig. 4).

According to Figure 1, most sectors of Kharkiv region economy that provide services may fall into Quadrant I of the matrix: including: "Education", "Healthcare and social assistance" and others. High growth rates of labor productivity and low relative level of labor productivity are characteristic to these sectors.

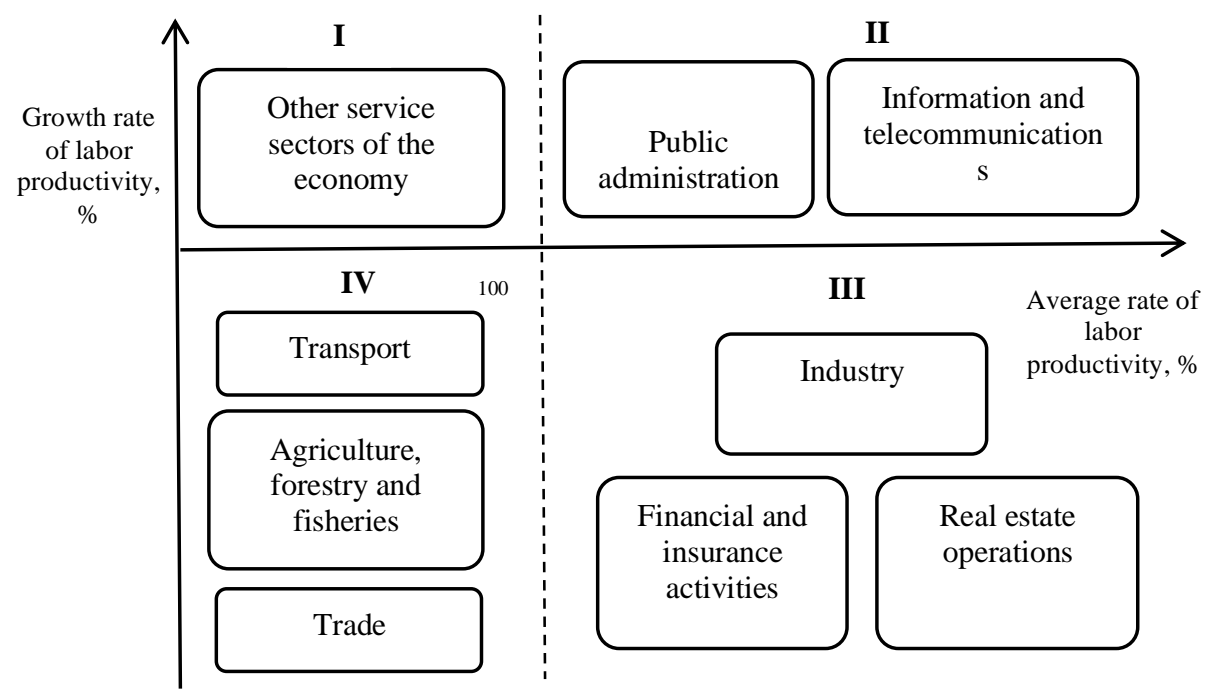

Fig. 4 Perspective structure of sectors of Kharkiv region economy according to the nochange scenario

Source: Authors'

Quadrant II includes "Public administration and defense; compulsory social insurance" sector with high relative labor indicators. Such tendency exists due to the prospective increase in material and technical base because of the military conflict in the East of Ukraine. "Information and telecommunications" sector also got to Quadrant II and it will be able to keep its positions due to the use of the latest technologies and a decrease in the average growth rate of labor productivity.

Such sectors of Kharkiv region economic activity as "Industry" and "Financial and insurance activities" will move from Quadrant II to Quadrant III. "Real estate operations" sector will remain in Quadrant III.

Quadrant IV of the matrix includes the following sectors of Kharkiv region economy: "Agriculture, forestry and fisheries" and "Transport, warehousing, postal and courier activities"; they are represented with the lowest relative labor indicators. "Wholesale and retail trade; repair of motor vehicles and motorcycles" sector will also go to Quadrant IV. In the strategic perspective, we can expect a "boom in unemployment" because overstaffing and low growth rates of the industry will affect mass dismissal of those employed in the field of trade. 
Therefore, functioning of the sectors of Kharkiv region economy under the scenario of constant (inertial) labor productivity for 5-10 years will provide positive indicators of the development of traditional sectors of economic activity for the territory, as well as for IT sector. However, the level of overall competitiveness of the region against the background of aging logistics and inefficient employment system will decline.

\subsection{Modernization scenario for different sectors of Kharkiv region economy on condition of available staffing}

Benchmarks for implementing modernization scenario for developing sectors of territorial economy is re-orienting the region's specialization based on competitive advantages, ensuring the optimal structure of employment, creating certain conditions for the successful implementation of the decentralization strategy, improving the efficiency of international integration in the region and so on.

The main prerequisite for the development of various economic activities on condition of available staffing in Kharkiv region is to reduce restrictions on the development of economic and public relations in the international space (Development Strategy of Kharkiv region, 2015). Promotion of economic interests of Kharkiv region to international markets will strengthen the position of the region in the international space, not only in the markets with traditional (for Kharkiv region) specialization (industrial, agricultural, service and trade sectors), but also in the latest high-tech markets.

In the framework of modernization scenario, "Industry", "Education" and "Information and telecommunications" will become the drivers of sustainable economic development of Kharkiv region. Moreover, labor productivity growth in these sectors may lead to a corresponding increase in other parts of the economic activities.

In the industrial sector, the increase in labor productivity to the world level will be due to the improvement of the state of fixed assets and the introduction of new technologies to the traditional branches of the processing industry (New industrialization - a real chance for Ukraine, 2018). Attraction of world brands to the industry will allow receiving consultations on professional training and provide further training to workers.

The increase in the real wage in this area will reduce the rate of migration of relevant professionals abroad. Taking into account the number of citizens who have already left Ukraine, according to the modernization scenario, scientific research indicates the gradual return of those emigrants who have already formed or will form readiness for re-emigration (Blyzniuk et al., 2018).

The increase in labor productivity in "Education" sector, in particular by improving social infrastructure of universities, will increase the attractiveness of Kharkiv region as a center for providing educational services in Europe and develop academic mobility among teachers and students. This, in turn, will affect the increase in productivity in "Professional, scientific and technical activities" sector through the transfer of knowledge, the commercialization of new technologies and the development of innovative entrepreneurship.

According to the modernization scenario, "Information and telecommunications" sector may increase the demand for human resources. Increasing youth employment in this sector in Kharkiv region will take place if a network of contacts between universities and the private sector is established. Expanding sectors that focus on digital solutions in Kharkiv region will increase the creation of GVA in other economic activities. 
The growth of labor productivity to the world level in the field of agriculture will occur due to the intensive use of land and the introduction of new technologies for processing agricultural products. On condition of creation of public-private partnership in a strategic perspective in this sector of Kharkiv region economy, it will be possible to overcome the existing mismatch in the skills of human resources in accordance with the needs of employers of the agricultural complex.

The functioning of the sectors of Kharkiv region economy according to the scenario of growth of labor productivity by types of economic activities to the world level allows making assumptions about the optimal structure of economic sectors in the future (Fig. 5).

It is predicted that Quadrant I of the matrix will include most sectors of Kharkiv region economy that provide non-market services: "Healthcare and social assistance", "Art, sports, entertainment and leisure", "Activities in the field of administrative and support services" and others. Quadrant I will also include "Construction" sector.

As expected, Quadrant II will include such sectors as "Information and telecommunications", "Industry"; "Education" sector will be added.

Economic activities such as "Financial and insurance activities" and "Agriculture, forestry and fisheries" will move to Quadrant III of the matrix from Quadrants II and IV respectively. This quadrant will also include "Real estate operations" and "Transport, warehousing, postal and courier activities".

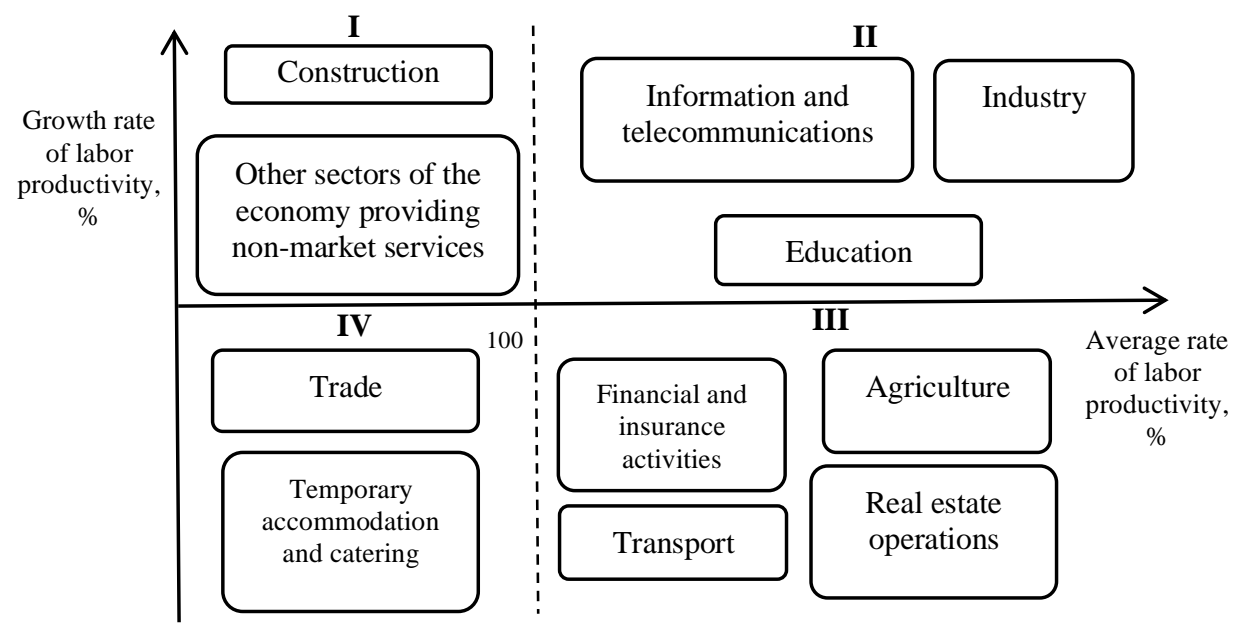

Fig. 5 Perspective structure of sectors of Kharkiv region economy in the framework of modernization scenario Source: Authors'

According to the indicator of labor productivity, Quadrant IV of the matrix will include the following types of economic activity: "Wholesale and retail trade; repair of motor vehicles and motorcycles" and "Temporary accommodation and catering".

Thus, in the strategic perspective, functioning of the sectors of Kharkiv region economy on condition of available staffing under the scenario of labor productivity growth to the world level will ensure sustainable economic development of the territory in accordance with the European principle of "Smart specialization". 
The diversity of research areas and the search for approaches to personnel management, including the regional level, sustainable development have been highlighted in the scientific works of foreign and domestic scientists: L. G. Kvasniy, W. Lewis, V.V.Onikienko, E. M. Libanova, S. McGuinness, V. V. Blyzniuk and others. The problem of the relationship between innovation and employment is the subject of scientific research by such foreign scientists as V. V. Roy, B. Balsmeier, M. Woerter, N. Lee, D. Acemoglu, D. Autor. The works of many scientists, including J. Fagerberg, S. Kryvusha, A. Tertichny, L. Makarova and others, are devoted to various aspects of the study of labour productivity as a catalyst for the effective use of human resources. At the same time, we should question the verification of the scenario direction of future staffing gaps that are determined by no-change dynamics of quantitative traits of human resources and the turbulence of technological changes in different sectors of the regional economy and when the corresponding changes in demand for human resources occur.

\section{CONCLUSION}

Based on the calculation of labor productivity by kinds of economic activities of Kharkiv region, we justified the policy of transformation for Kharkiv region economy, which is oriented to growing sectors with high productivity. In the strategic perspective, this policy will determine the formation of an effective employment structure, in accordance with the global challenges that shape modern workplace.

The use of a matrix approach to the definition of strategic staffing gaps according to the sectors of Kharkiv region economy is proposed. Quadrant I includes most sectors of the region economy that provide non-market services, as well as the sphere of trade, with high growth rates and a small relative share of labor productivity. Quadrant II includes "Information and telecommunications", "Industry", "Financial and insurance activities" and others with the highest indicators of labor productivity. Quadrant III includes such sectors of the economy as "Real estate operations" and "Transport", with low growth rates and a significant relative share of labor productivity. The quadrant with the lowest productivity indicators includes "Agriculture, forestry and fisheries", "Administrative services" and others. The scenarios of redistribution of human resources to the industry with high productivity and the corresponding changes in the employment structure of Kharkiv region were given.

The development of sectorial scenarios for the development of Kharkiv region on condition of available staffing, specifics and features of the territory provides an opportunity to form recommendations for effective management of human resources in the region, which will further settle the contradictions of sustainable development of the territory.

It is revealed that the functioning of the sectors of Kharkiv region economy, under the scenario of constant (inertial) labor productivity for 5-10 years, will provide positive indicators of the development of the traditional sectors for the territory, as well as for the IT sector. Nevertheless, the level of overall competitiveness of the region against the background of aging logistics and inefficient employment system will decline. This will negatively affect the ability to attract funds to the region and the functioning of industries that provide nonmarket services. This, in turn, will affect the degradation of residential areas in Kharkiv region, the reduction of the working-age population, the increase in the load on one working person at the expense of pensioners, and it will create prerequisites for the outflow of human resources. 
It is determined that "Industry", "Education" and "Information and telecommunications" sectors will become the drivers of sustainable economic development of Kharkiv region in the long term. These sectors of Kharkiv region economy will only function on condition of available staffing in the framework of modernization scenario. Labor productivity growth will provoke a corresponding increase in other parts of the economic activities of the region. In addition, it is argued that the development of Kharkiv region under the scenario of productivity growth will ensure sustainable economic development of the territory in accordance with the European principle of "Smart specialization".

Therefore, the trends of staffing should be considered as one of the central directions of the regional development under the influence of the fourth industrial revolution. Creation of infrastructure, protection of resources, and formation of the business climate are strategically important measures to introduce positive changes to the territory in the face of new opportunities and challenges. However, bridging strategic staffing gaps can become the basis for intensive development of the territory.

\section{REFERENCES}

Acemoglu, D. H., \& Autor, D. (2011). Skills, tasks and technologies: implications for employment and earnings. Elsevier, Amsterdam.

Balsmeier, B., \& Woerter, M. (2019). Is this time different? How digitalization influences job creation and destruction. Research Policy, 48, 62-73.

Blyzniuk, V., \& Paslavska V. (2018). Ukrayinskij rinok praci: imperativi ta mozhlivosti zmin [The Ukrainian labor market: imperatives and opportunities for change]. Retrieved from: http://ief.org.ua/docs/mg/306.pdf, Accessed on: 16 May 2019.

Brynjolfsson, E., \& McAfee, A. (2014). The Second Machine Age: Work, Progress, and Prosperity in a Time of Brilliant Technologies. WW Norton \& Company, New York.

Development Strategy of Kharkiv region by 2020 (2015), Retrieved from: https://kharkivoda.gov.ua/content/ documents/431/43045/files/new-563_SRR2020.pdf, Accessed on: 6 June 2019.

Fagerberg, J. (2000). Technological progress, structural change and productivity growth: a comparative study. Structural Change and Economic Dynamics, 11, 393-411.

Kharkiv IT Research (2018), Retrieved from: https://www.slideshare.net/ITcluster/kharkivitresearchreport-118970190, Accessed on: 5 May 2019.

Kryvusha, S. (2017). Otsinka produktyvnosti pratsi v sektori posluh [Evaluation of labor productivity in the services sector]. Young Scientist, 12(52), 665-669.

Kvasniy, L., \& Paslavska, V. (2014). Rol' ekonomichnoho potentsialu rehionu v zabezpechenni stiykoho rozvytku ekonomiky [The Role of the Economic Potential of the Region to Ensure Sustainable Economic Development]. Economic herald of the Donbas, 2(36), 85-89.

Kyfyak, V. (2016). Teoretychni osnovy stsenarnoho prohnozuvannya sotsial'no-ekonomichnoho rozvytku prykordonnoho rehionu [Theoretical grounds for scenario forecasting of socioeconomic development of a border region]. Actual problems of economics, 7(181), 214-222.

Lee, N., \& Clarke, S. (2019). Do low-skilled workers gain from high-tech employment growth? Hightechnology multipliers, employment and wages in Britain. Research Policy, 48, 1-11.

Lewis W. (1954). Economic Development with Unlimited Supplies of Labour. The Manchester School.

Libanova, E. (2015). Liudskyi rozvytok v Ukraini. Modernizatsiia sotsialnoi polityky: rehionalnyi aspekt [Human development in Ukraine. Social policy modernization: a regional dimension], Retrieved from: https://idss.org.ua/monografii/2016_Lud_rozv_monogr.pdf, Accessed on: 25 March 2019.

McKinsey Global Institute (2017). Technology, jobs, and the future of work, Retrieved from: https://www.mckinsey.com/featured-insights/employment-and-growth/technology-jobs-and-the-future-ofwork\#, Accessed on: 29 April 2019.

McGuinness, S. (2017). How Useful Is the Concept of Skills Mismatch, International Conference on Jobs and Skills Mismatch, Retrieved from: http://www.ilo.org/skills/events/WCMS_538198/lang--en/index.htm, Accessed on: 11 June 2019.

Nerdrum, L., \& Truls, E. (2001). Intellectual Capital: A Human Capital Perspective. Journal of Intellectual Capital, 2, 127-135. 
Nova industrializaciya - real`ny`j shans dlya Ukrayiny` [New industrialization - a real chance for Ukraine] (2018), Retrieved from: https://uspp.ua/assets/doc/maket_nov_2019.pdf, Accessed on: 30 April 2019.

Onikiienko, V. (2013). Rynok pratsi ta sotsialnyi zakhyst naselennia Ukrainy: retroanaliz, problemy, shliakhy [Labor market and social protection of Ukrainian population: retroanalysis, problems, ways], Retrieved from: https://idss.org.ua/monografii/2013_rynok_praci_onikienko.pdf, Accessed on: 25 April 2019.

Semykina, M., \& Ishchenko, N. (2012). Motyvatsiia efektyvnoi zainiatosti poshuk optymalnoi stratehii [Motivation for effective employment: finding the optimal strategy], Retrieved from: https://core.ac.uk/ reader/84826460, Accessed on: 25 May 2020.

Tertichny, A., Makarova, L. (2015). Stan produktyvnosti pratsi na terytoriyi suchasnoyi Ukrayiny [State of the productivity of labor in the territory of modern Ukraine]. Economic sciences, 2, 199-206.

The Future of Jobs (2018). Retrieved from: http://www3.weforum.org/docs/WEF_Future_of_Jobs_2018.pdf, Accessed on: 20 April 2019.

Ukrainian students abroad: how many and why? (2018). Retrieved from: https://cedos.org.ua/uk/articles/ ukrainske-studentstvo-za-kordonom-dani-do-201718-navchalnoho-roku, Accessed on: 25 May 2019.

Ukrayinske suspilstvo: migracijnij vimir [Ukrainian society: a migration dimension] (2018). Retrieved from: https://www.idss.org.ua/arhiv/Ukraine_migration.pdf, Accessed on: 20 May 2019.

Vartanova, O. (2018). Rozvitok servisnoyi ekonomiki v umovah globalizaciyi [Development of service economy in the conditions of globalization]. International Scientific-Practical Conference, 38-40.

Vincent V. R. (2018). Technology and employment: Mass unemployment or job creation? Empirical evidence from European patenting firms. Research Policy, 47, 1762-1776.

\section{ZAPOŠLJAVANJE ZA SCENARIJE ODRŽIVOG RAZVOJA EKONOMSKIH SEKTORA U REGIONU HARKOVA}

Ovaj članak se bavi proučavanjem pojave i produbljavanja jaza u zapošljavanju koji utiče na razvoj regije pod uticajem transformišuće proizvodne dominante u uslovima Ekonomije 4.0. $U$ sklopu rada, daje se generalizacija sistema faktora za pojavu jaza u zapošljavanju koji utiče na održivi razvoj regije. Predstavljena je matrica kojea određuje jaz u zapošljavanju i razvijeni su sektorski scenariji za sprečavanje ovog jaza u regionalnoj ekonomiji Harkova. Stvorena je pretpostavka o mogućoj strukturi ekonomskih sektora u regionu Harkova prema scenarijima inertnog, odnosno inovativnog načina razvoja Ukrajine.

Ključne reči: Ekonomija 4.0; ljudski resursi; jaz u zapošljavanju; tehnologija; održivi razvoj 